\title{
Programmed death ligand 1 expression in early stage, resectable non-small cell lung cancer
}

\author{
Manolo D'Arcangelo", Armida D'Inceccoㄹ, Claudia Ligorioo ${ }^{3}$, Stefania Damiani ${ }^{3}$, \\ Maurizio Puccetti ${ }^{4}$, Sara Bravaccini ${ }^{5}$, Luigi Terracciano ${ }^{6}$, Chiara Bennati ${ }^{1}$, Gabriele \\ Minuti $^{1}$, Silvia Vecchiarelli ${ }^{1}$, Lorenza Landi ${ }^{1}$, Marina Milesi ${ }^{7}$, Alberto Meroni ${ }^{8}$, Sara \\ Ravaioli ${ }^{5}$, Maria Maddalena Tumedei ${ }^{5}$, Matteo Incarbone ${ }^{8}$ and Federico Cappuzzo ${ }^{1}$ \\ ${ }^{1}$ AUSL della Romagna, Department of Oncology-Hematology, Ravenna, Italy \\ ${ }^{2}$ University Hospital of Siena, Medical Oncology and Immunotherapy, Center for Immuno-Oncology, Siena, Italy \\ ${ }^{3}$ University of Bologna, DIMES, Pathology, Bologna, Italy \\ ${ }^{4}$ AUSL della Romagna, Department of Pathology, Ravenna, Italy \\ ${ }^{5}$ Istituto Scientifico Romagnolo per lo Studio e la Cura dei Tumori IRCSS, Bioscences Laboratory, Meldola, Italy \\ ${ }^{6}$ University Hospital Basel, Institute of Pathology, Basel, Switzerland \\ ${ }^{7}$ Clinica San Carlo, Service of Pathology, Paderno Dugnano, Italy \\ ${ }^{8}$ RCCS MultiMedica, Thoracic Surgery, Sesto S.G., Italy \\ Correspondence to: Federico Cappuzzo, email: federico.cappuzzo@auslromagna.it
}

Keywords: PD-L 1; NSCLC; prognosis; tumor grading

Received: April 25, $2018 \quad$ Accepted: December 10, $2018 \quad$ Published: January 15, 2019

Copyright: D'Arcangelo et al. This is an open-access article distributed under the terms of the Creative Commons Attribution License 3.0 (CC BY 3.0), which permits unrestricted use, distribution, and reproduction in any medium, provided the original author and source are credited.

\section{ABSTRACT}

Introduction: For several years non-small cell lung cancer (NSCLC) has been considered non-immunogenic. Recent advances in antitumor immunity brought to the discovery of checkpoints that modulate immune response against cancer. One of them is programmed death receptor 1 (PD-1) and its ligand (PD-L1). Although PD-L1 expression seems predictive of response to anti-PD-1/PD-L1 agents, its prognostic value is unclear. In this study we investigated the prognostic value of PD-L1 expression and its correlation with clinical-pathological characteristics in a cohort of surgically resected NSCLC.

Material and methods: PD-L1 expression was evaluated in 289 surgically resected NSCLC samples by immunohistochemistry. Our cohort included patients not exposed to adjuvant chemotherapy. PD-L1 status was defined as: 1) PD-L1 high (tumor proportion score, TPS $\geq 50 \%$ ), PD-L1 low (TPS 1-49\%), PD-L1 negative (TPS $<1 \%$ ); 2) PD-L1 positive (TPS $\geq 50 \%$ ) and negative (TPS $<50 \%$ ); 3 ) as a continuous variable.

Results: Patients were mostly males $(79 \%)$, former or current smokers $(81 \%)$, with a median age of 67 years, non-squamous histology $(67.5 \%)$ and high-grade tumors (55\%). PD-L1 tumors were $18.7 \%$. There was no significant association with sex, age, smoking status and histology. A strong correlation between high PD-L1 expression and tumor grade was detected. The difference in median $O S$ in the different groups of patients was not statistically significant.

Conclusion: PD-L1 is not prognostic in surgically resected NSCLC. The association with tumor differentiation suggests that grading could represent an easy-to-assess tool for selecting subjects potentially sensitive to immunotherapy warranting further investigations. 


\section{INTRODUCTION}

Lung cancer is the most common cause of cancerrelated deaths worldwide. It accounts for $14 \%$ of new diagnoses and for 1 in 4 cancer deaths. It is usually diagnosed in advanced stage and survival of metastatic patients remains disappointing [1]. Lung cancer is a heterogeneous disease, including two major histologic categories: Small-Cell Lung Cancer (15-20\% of cases) and Non-Small-Cell Lung Cancer (NSCLC, 80-85\% of cases). The latter includes adenocarcinoma $(60 \%)$, squamous cell carcinoma (25\%), large cell carcinoma $(10 \%)$ and other less common histologic subtypes [2]. Deeper understanding of NSCLC biology has recently brought to notable improvement in its treatment thanks to the introduction of target agents for tumors with specific oncogene aberrations. Despite these advances, prognosis of patients with lung cancer remains poor especially for those who do not harbor a driver mutation.

For a long time lung cancer has been considered as non-immunogenic for the lack of activity of therapeutic approaches with cytokines, although the wide T-cell infiltration observed in pathological samples [3, 4]. The discovery of immune checkpoints as regulators of immune response has granted new important insights for the understanding of antitumor immunity. Under normal conditions immune checkpoints are responsible for the balancing of pro- and anti-immune signals within immune cells, allowing the physiological mechanism of self-tolerance [5]. Tumor cells are able to hijack immune-modulatory mechanisms thus ensuring evasion of the immune system surveillance and tumor growth and survival [6]. Some of these mechanisms include reduced expression of the major histocompatibility complex molecules, loss of tumor antigens, production of immunosuppressive mediators and expression of inhibitory checkpoint ligands [7]. Several checkpoints have been identified so far and among them one of the most important is the programmed death receptor 1(PD-1)/ programmed death ligand 1 (PD-L1) axis.

PD-L1 (CD247 or B7-homolg 1, B7-H1) is a type I transmembrane glycoprotein and the principal ligand of PD1. It is widely expressed on dendritic cells, lymphocytes, macrophages, mast cells, endothelial and epithelial cells [8]. Furthermore, expression of PD-L1 occurs in several tumors, including lung cancer [9-40]. Two anti-PD-1 agents, nivolumab and pembrolizumab, and one anti-PD-L1 agent, atezolizumab, have been approved over the last three years for the treatment of metastatic NSCLC and other agents are under investigation. In the Keynote 024 study, pembrolizumab effectively prolonged survival of NSCLC patients expressing PD-L1 in at least $50 \%$ of tumor cells compared to platinum-based chemotherapy in first-line setting [41-42]. Conversely, in the CheckMate 026 study nivolumab failed to produce a survival benefit compared to chemotherapy in first-line setting even in the subgroup of individuals with high levels of PD-L1 expression [43]. However, nivolumab significantly prolonged survival compared to docetaxel in second-line setting irrespective of PD-L1 levels [44-45]. A plethora of clinical trials are evaluating the combination of immunotherapy with chemotherapy, target therapies or other immune-directed agents; other trials are exploring immunotherapy in the neoadjuvant and adjuvant settings [46-48]. Although PDL1 expression seems predictive for sensitivity to anti-PD-1/ PD-L1 strategies, its prognostic impact remains unclear in early as well as in advanced disease $[9,10,12,13-15,17$, 19, 21-23, 25-28, 35-40].

In this study we aimed to investigate the prognostic value of high levels of PD-L1 expression and its association with clinical and pathological features in a cohort of surgically resected NSCLC patients not exposed to adjuvant chemotherapy.

\section{RESULTS}

\section{Patient characteristics}

The characteristics of patients are shown in Table 1. The majority of patients were male (79\%) and the median age was 67 years (range: 23-89). About one third of tumors were classified as having squamous differentiation (31.1\%) based on the immunohistochemistry (IHC) positive staining for $\mathrm{p} 40$ and about half of the tumors were poorly differentiated $(55 \%)$. Although data on smoking exposure were available for a small percentage of cases, the majority of patients with a complete smoking history were smokers at the time of lung cancer surgery $(81.6 \%)$. Our cohort included patients treated with radical surgery before chemotherapy became a standard treatment and before the approval of any target therapy. For such reason no information on epidermal growth factor receptor $(E G F R)$, anaplastic lymphoma kinase $(A L K)$ or ROS protoncogene $1($ ROS- 1$)$ status was available.

\section{PD-L1 expression and correlation to clinical- pathological characteristics}

Among the 289 tumors analyzed for this study, 176 $(60.9 \%)$ were negative for PD-L1 expression on tumor cells (tumor proportion score, TPS <1\%), $59(20.4 \%)$ showed only weak staining (TPS 1-49\%) and 54 (18.7\%) were strongly positive (TPS $\geq 50 \%$ ). The PD-L1 score obtained from the two cores of the same tumor was concordant in most cases (97.9\%). In case of discordance $(2.1 \%)$, the final score was obtained calculating the average value of the two scores.

Table 2 shows the correlation of PD-L1 status to clinical characteristics. No significant correlation to sex $(\mathrm{p}=0.64)$, smoking habit $(\mathrm{p}=0.17)$ and histology $(\mathrm{p}=0.34)$ 
Table 1: Patients characteristics

\begin{tabular}{|c|c|c|}
\hline & Total & $\%$ \\
\hline Total no. of patients & 289 & 100 \\
\hline Median age, years (range) & $67(23-87)$ & \\
\hline \multicolumn{3}{|l|}{ Gender } \\
\hline Male & 229 & 79 \\
\hline Female & 60 & 21 \\
\hline \multicolumn{3}{|l|}{ Histology } \\
\hline Adenocarcinoma & 187 & 64.7 \\
\hline Squamous & 90 & 31.1 \\
\hline Other & 12 & 4.2 \\
\hline \multicolumn{3}{|l|}{ Grading } \\
\hline 1 & 14 & 4.8 \\
\hline 2 & 107 & 37 \\
\hline 3 & 148 & 51.2 \\
\hline Not defined & 20 & 7 \\
\hline \multicolumn{3}{|l|}{ Disease stage (TNM $7^{\text {th }}$ ed) } \\
\hline $\mathrm{I}$ & 80 & 27.7 \\
\hline II & 70 & 24.2 \\
\hline IIIA & 76 & 26.3 \\
\hline IIIB & 5 & 1.7 \\
\hline Not defined & 58 & 20.1 \\
\hline \multicolumn{3}{|l|}{ Smoking status } \\
\hline Available/not available & $49 / 240$ & $17 / 83$ \\
\hline Smoker/Non-smoker & $40 / 9$ & $81.6 / 18.4$ \\
\hline
\end{tabular}

was detected among the PD-L1 high, low and negative groups. Interestingly, there was a strong, statistically significant association of PD-L1 status with grading: strong PD-L1 expression was observed mostly among grade 3 tumors (72\%), while only $27 \%$ of grade 2 tumors and no grade 1 tumor expressed PD-L1 at high levels $(p=0.02)$. When the population was divided in PD-L1 positive and negative this correlation was even stronger: $25 \%$ of grade 3 tumors showed high levels of expression while only $13.1 \%$ of grade 1-2 tumors expressed the ligand $(\mathrm{p}=0.005$, Figure 1$)$.

No association with any clinical characteristic was observed when the statistical analysis was performed considering PD-L1 expression as a continuous variable, with the only exception of tumor grading $(p=0.02)$.

\section{Prognostic impact of PD-L1 expression}

OS data was available for 271 patients. No difference in overall survival (OS) was detected between PD-L1 positive (TPS $\geq 50 \%$ ) and negative (TPS $<50 \%$ ) (PD-L1 positive vs negative: 47.6 vs 32.2 months, $p=0.51$, Figure 2A). When patients were divided in PD-L1 high (TPS $\geq 50 \%$ ), low (TPS 1-49\%) and negative (TPS $<1 \%$ ) we detected no correlation between PD-L1 status and survival (PD-L1 high vs low vs negative: 47.6 vs 31.3 vs 32.2 months, Figure 2B). Considering the strong association between tumor grade and PD-L1 expression, we restricted the analysis to patients with grade 3 tumors. Even in this subgroup of subjects, no difference in survival according to PD-L1 status was detected (Figure 2C and 2D). 
Table 2: Correlation of PD-L1 status to clinical-pathological features

\begin{tabular}{|c|c|c|c|c|}
\hline & $\begin{array}{c}\text { PD-L1 < } \% \\
\text { N }(\%)\end{array}$ & $\begin{array}{c}\text { PD-L1 1-49\% } \\
\text { N (\%) }\end{array}$ & $\begin{array}{c}\text { PD-L1 } \geq \mathbf{5 0 \%} \\
\text { N (\%) }\end{array}$ & p value \\
\hline \multicolumn{5}{|l|}{ Gender } \\
\hline Male & $139(18.3 \%)$ & 49 & $41(81.7 \%)$ & $p=0.64$ \\
\hline Female & $37(20 \%)$ & 10 & $13(80 \%)$ & \\
\hline \multicolumn{5}{|l|}{ Histology } \\
\hline Non-squamous & $118(63.1 \%)$ & $37(19.8 \%)$ & $32(17.1 \%)$ & $p=0.34$ \\
\hline Squamous & $49(54.4 \%)$ & $20(22.2 \%)$ & $21(23.3 \%)$ & \\
\hline \multicolumn{5}{|l|}{ Grading } \\
\hline $1+2$ & $81(66.9 \%)$ & $26(21.5 \%)$ & $14(11.6 \%)$ & $p=0.02$ \\
\hline 3 & $83(56.1 \%)$ & $28(18.9 \%)$ & $37(25 \%)$ & \\
\hline \multicolumn{5}{|l|}{ Smoking status } \\
\hline Ever smoker & $25(62.5 \%)$ & $10(25 \%)$ & $3(33.3 \%)$ & $\mathrm{p}=0.17$ \\
\hline Never smoker & $4(44.4 \%)$ & $2(22.2 \%)$ & $5(12.5 \%)$ & \\
\hline
\end{tabular}

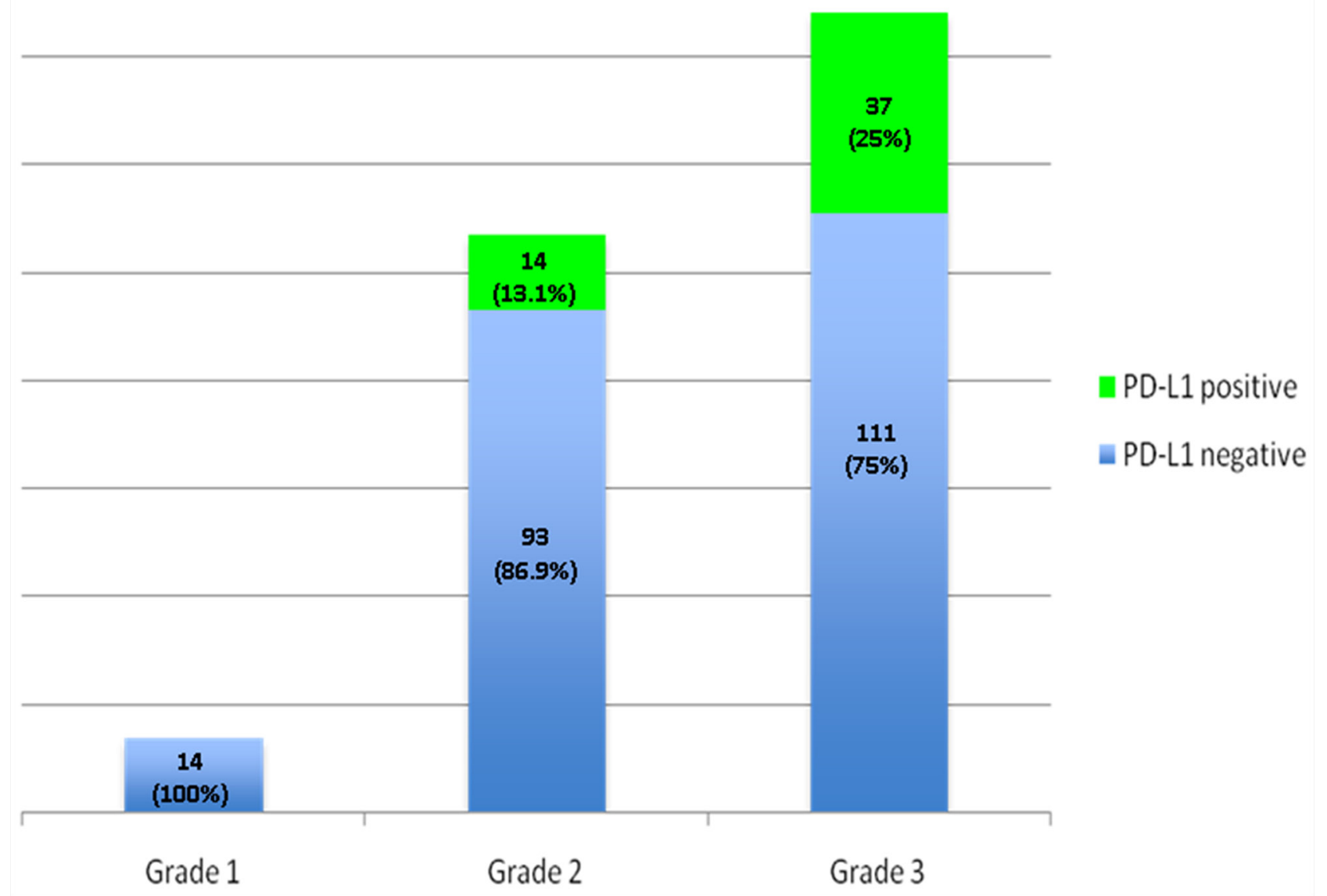

Figure 1: PD-L1 positivity correlation to tumor differentiation grade: StrongPD-L1 expression is statistically more common in grade 3 tumors compared to grade 1 and 2 tumors. 
A

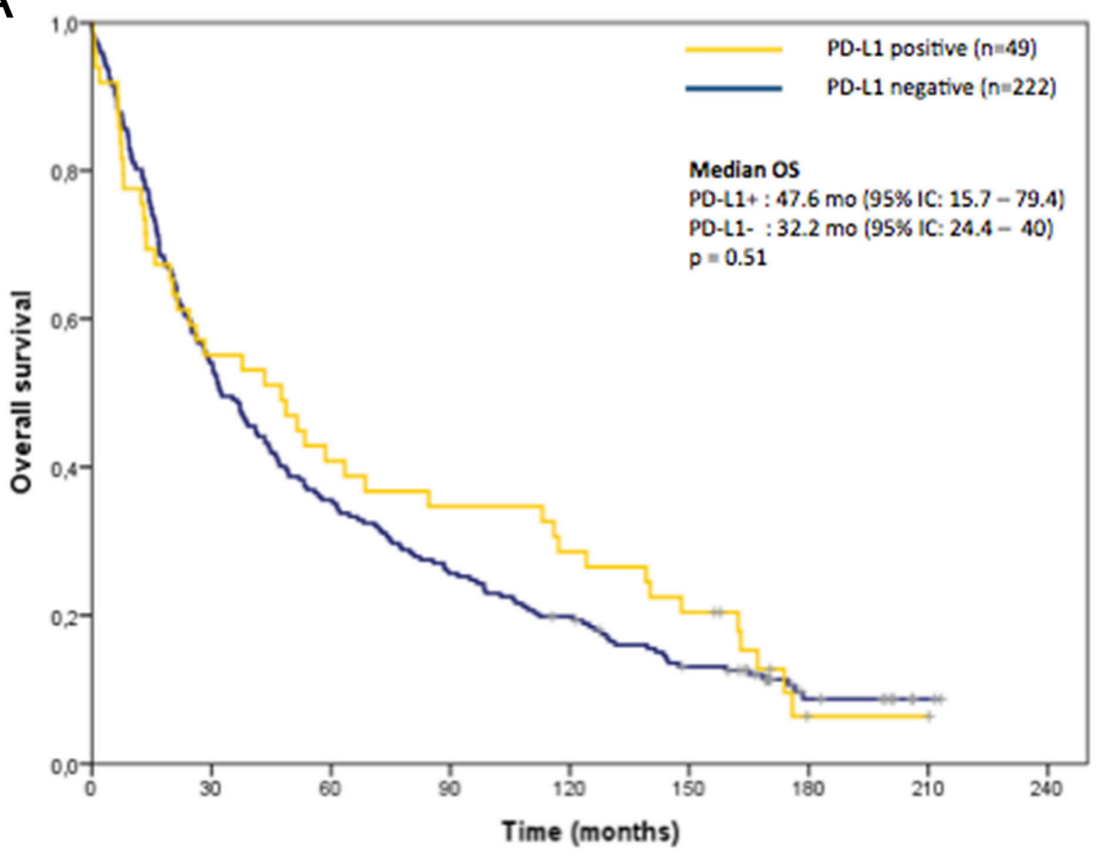

\begin{tabular}{rrrrrrrr}
\hline PD-L1 & 30 & 60 & 90 & 120 & 150 & 180 & 210 \\
\hline Negative & 120 & 79 & 57 & 43 & 26 & 8 & 2 \\
Positive & 27 & 20 & 17 & 14 & 10 & 1 & 1 \\
\hline
\end{tabular}

B

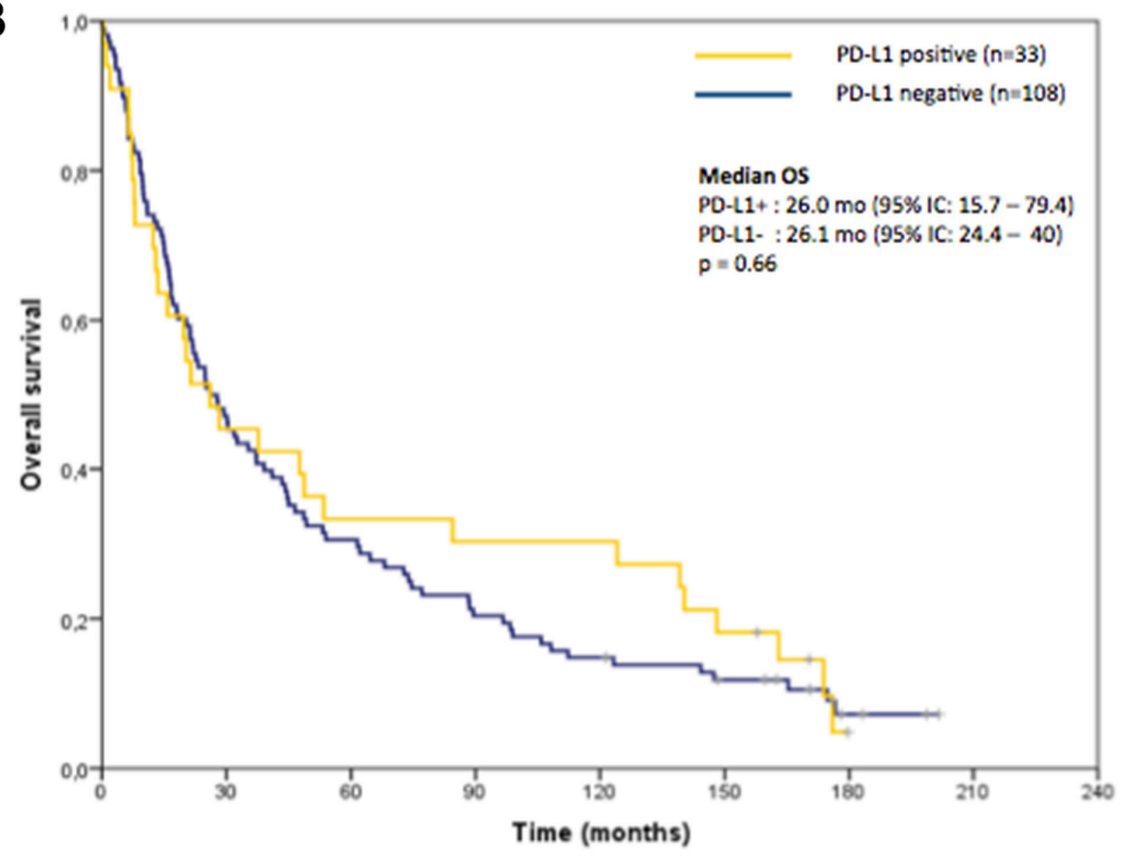

\begin{tabular}{rrrrrrrr}
\hline PO-L1 & 30 & 60 & 90 & 120 & 150 & 180 & 210 \\
\hline Negative & 51 & 33 & 22 & 15 & 11 & 3 & 0 \\
Positive & 15 & 11 & 10 & 10 & 6 & 0 & 0 \\
\hline
\end{tabular}

Figure 2: Kaplan-Meier curves of overall survival of the whole cohort $(\mathbf{A}, \mathbf{B})$ and grade 3 tumors $(\mathbf{C}$, D): No statistically significant difference in overall survival was observed between the several PD-L1 groups of patients. 

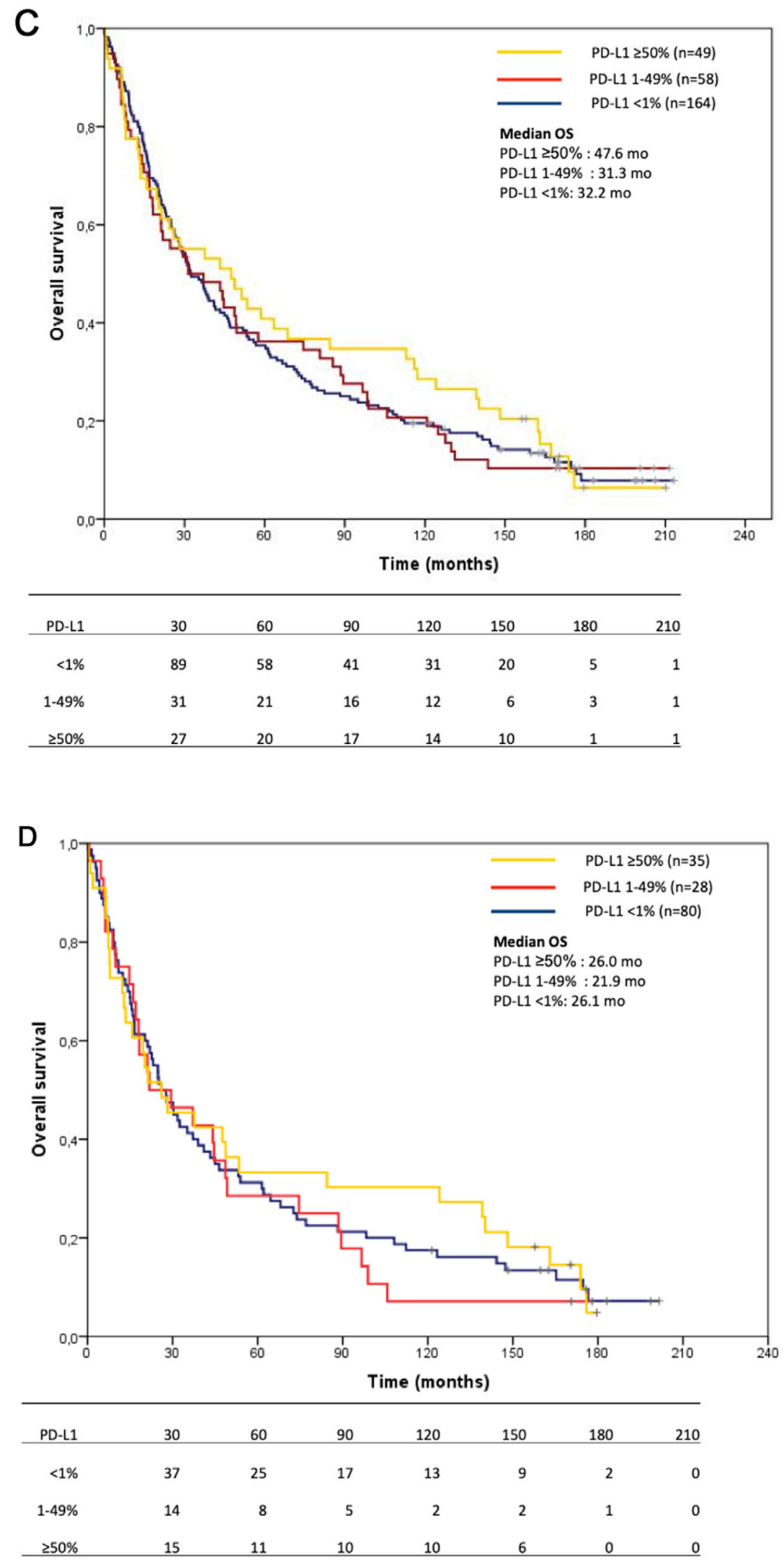

Figure 2: (Continued) Kaplan-Meier curves of overall survival of the whole cohort (A, B) and grade 3 tumors (C, D): No statistically significant difference in overall survival was observed between the several PD-L1 groups of patients. 
Table 3: Published studies on the prognostic significance of PD-L1 expression in NSCLC

\begin{tabular}{|c|c|c|c|c|c|c|c|c|}
\hline Author & Year & Histology & Population & $\begin{array}{c}\mathbf{N}^{\circ} \\
\text { samples }\end{array}$ & $\begin{array}{l}\text { PD-L1 Ab } \\
\text { clone }\end{array}$ & $\begin{array}{c}\text { PD-L1 } \\
\text { positivity } \\
\text { cut-off }(\%)\end{array}$ & $\begin{array}{l}\text { PD-L1 } \\
+(\%)\end{array}$ & $\begin{array}{c}\text { Prognostic } \\
\text { role (Pos/ } \\
\text { Neg/No) }\end{array}$ \\
\hline Zhou C [12] & 2017 & Adenocarcinoma & Asian & 108 & SP263 & H-score $\geq 1$ & 40,7 & $\mathrm{Neg}$ \\
\hline Yvorel V [13] & 2017 & Sarcomatoid & Caucasian & 36 & E1L3N & $\geq 5$ & 75 & Pos \\
\hline Zhang M [14] & 2017 & Squamous & Asian & 84 & $\begin{array}{c}\text { Abcam }(28- \\
8)\end{array}$ & $\begin{array}{c}>5 \text { (at least } \\
2+\text { ) }\end{array}$ & 58,3 & $\mathrm{Neg}$ \\
\hline Wu S [15] & 2017 & Adenocarcinoma & Asian & 133 & SP263 & $>25$ & 16,5 & Neg \\
\hline \multirow[t]{3}{*}{ Tsao M-S [16] } & 2017 & All & Caucasian & 982 & E1L3N & $\geq 1$ & 32 & No \\
\hline & & & & & & $\geq 25$ & 20,8 & No \\
\hline & & & & & & $\geq 50$ & 14,3 & No \\
\hline Okita R [17] & 2017 & All & Asian & 91 & SP142 & H-score $\geq 100$ & 14 & $\mathrm{Neg}$ \\
\hline Igawa S [18] & 2017 & All & Asian & 229 & SP263 & $\mathrm{H}$-score $\geq 20$ & 52 & No \\
\hline \multirow[t]{4}{*}{ Takada K [19] } & 2017 & Squamous & Asian & 205 & SP142 & $\geq 1$ & 51,7 & $\mathrm{Neg}$ \\
\hline & & & & & & $\geq 5$ & 35,1 & No \\
\hline & & & & & & $\geq 10$ & 29,7 & No \\
\hline & & & & & & $\geq 50$ & 18 & No \\
\hline Fend L [20] & 2017 & All & Caucasian & 55 & E1L3N & $>5$ & 27,3 & No \\
\hline Guo Q [21] & 2017 & Squamous & Asian & 128 & Ab58810 & $\mathrm{IRS} \geq 3$ & 61,7 & Neg \\
\hline \multirow[t]{2}{*}{ Shimoji M [22] } & 2016 & Adenocarcinoma & Asian & 165 & E1L3N & H-score $\geq 5$ & 22 & Neg \\
\hline & & Squamous & & 55 & & & 60 & No \\
\hline Sterlacci W [23] & 2016 & All & Caucasian & 293 & E1L3N & $>5$ & 12 & Neg \\
\hline Song Z [24] & 2016 & Adenocarcinoma & Asian & 385 & Proteintech & $\geq 5$ & 48,3 & No \\
\hline $\begin{array}{l}\text { Ameratunga } \mathrm{M} \\
{[25]}\end{array}$ & 2016 & All & Caucasian & 522 & E1L3N & $\geq 50$ & 24 & $\begin{array}{l}\text { No (whole } \\
\text { pop); Neg } \\
\text { (EGFR+) }\end{array}$ \\
\hline Inamura K [26] & 2016 & Adenocarcinoma & Asian & 268 & E1L3N & $\geq 5$ & 16 & $\mathrm{Neg}$ \\
\hline Mori S [27] & 2017 & Adenocarcinoma & Asian & 296 & EPR1611 & $\begin{array}{c}\text { Modified } \\
\text { H-score } \geq 50\end{array}$ & 36 & $\mathrm{Neg}$ \\
\hline Sorensen SF [28] & 2016 & All & Caucasian & 177 & Ab58810 & $\geq 5$ & 37,9 & Pos \\
\hline Vieira T [29] & 2016 & Sarcomatoid & Caucasian & 75 & B7H1 & $\geq 5$ & 53 & No \\
\hline Yang CY [10] & 2016 & Squamous & Asian & 105 & NR & $\geq 5$ & 56,2 & Pos \\
\hline \multirow[t]{2}{*}{ Sun JM [30] } & 2016 & All & Asian & 1070 & E1L3N & $\geq 1$ & 45 & No \\
\hline & & & & & & $\geq 50$ & 6 & No \\
\hline $\begin{array}{l}\text { Dix Junqueira } \\
\text { Pinto G. [31] }\end{array}$ & 2016 & All & Caucasian & 177 & Ab58810 & $\geq 5$ & 32.8 & No \\
\hline Tang Y [32] & 2015 & NSCLC & Asian & 170 & E1L3N & H-score $\geq 5$ & 65,9 & No \\
\hline Kim S [33] & 2015 & Squamous & Asian & 331 & E1L3N & $\geq 10$ & 26,9 & No \\
\hline Schimdt LH [34] & 2015 & All & Caucasian & 321 & E1L3N & $\begin{array}{c}\geq 5 \text { (at least } \\
2+)\end{array}$ & 24 & No \\
\hline
\end{tabular}

(Continued) 


\begin{tabular}{|c|c|c|c|c|c|c|c|c|}
\hline Author & Year & Histology & Population & $\begin{array}{c}\mathbf{N}^{\circ} \\
\text { samples }\end{array}$ & $\begin{array}{l}\text { PD-L1 Ab } \\
\text { clone }\end{array}$ & $\begin{array}{c}\text { PD-L1 } \\
\text { positivity } \\
\text { cut-off }(\%)\end{array}$ & $\begin{array}{l}\text { PD-L1 } \\
+(\%)\end{array}$ & $\begin{array}{c}\text { Prognostic } \\
\text { role (Pos/ } \\
\text { Neg/No) }\end{array}$ \\
\hline Cooper WA [35] & 2015 & All & Caucasian & 678 & $22 \mathrm{C} 3$ & $\geq 50$ & 7,7 & Pos \\
\hline Lin C [36] & 2015 & $\begin{array}{c}\text { Adenocarcinoma } \\
\text { EGFRmut }+\end{array}$ & Asian & 63 & Ab58810 & $\begin{array}{l}\text { Mean IRS } \\
\text { score }\end{array}$ & 53,6 & Pos \\
\hline \multirow[t]{2}{*}{ Velcheti V [9] } & 2014 & All & Caucasian & 155 & $5 \mathrm{H} 1$ & $\begin{array}{c}>\text { normal } \\
\text { lung }\end{array}$ & 36,1 & Pos \\
\hline & & & & 303 & & & 24,8 & Pos \\
\hline Zhang Y [37] & 2014 & Adenocarcinoma & Asian & 143 & SAB2900365 & Quickscore $>8$ & 49 & $\mathrm{Neg}$ \\
\hline Yang CY [10] & 2014 & Adenocarcinoma & Asian & 163 & Proteintech & $\geq 5$ & 39,9 & No \\
\hline Azuma K [38] & 2014 & All & Asian & 164 & $\begin{array}{c}\text { Lifespan } \\
\text { Bioscience }\end{array}$ & H-score $>30 \%$ & 50 & $\mathrm{Neg}$ \\
\hline Chen YB [39] & 2012 & All & Asian & 120 & $236 \mathrm{~A} / \mathrm{E} 7$ & $\mathrm{IRS} \geq 3$ & 57,5 & $\mathrm{Neg}$ \\
\hline $\mathrm{Mu}$ CY [40] & 2011 & All & Asian & 109 & NR & $\begin{array}{c}\text { Mean } \\
\text { H-score (NR) }\end{array}$ & 53,2 & Neg \\
\hline
\end{tabular}

\section{DISCUSSION}

In the present study, specifically conducted in a NSCLC population not exposed to the potentially confounding effect of adjuvant chemotherapy, we showed that high levels of PD-L1 expression were not prognostic. Although PD-L1 expression was not associated with any specific clinical characteristic, we observed a strong association with tumor differentiation grade.

In NSCLC, biomarker analysis is not feasible in all patients mainly because of the scarce availability of tumor tissue. PD-L1 expression is not a perfect biomarker and much effort is being put in the research of more precise and reliable predictive markers for immunotherapy. An exploratory retrospective analysis of the CheckMate 026 study showed that high tumor mutation burden (TMB) identifies patients benefiting more from nivolumab than chemotherapy [49]. The same analysis detected no association between TMB status and PD-L1 expression [49]. No data are currently available on the association between TMB and differentiation grade, but it is possible that tumors with high somatic mutation burden are poorly differentiated. Support to this hypothesis comes from the recent observation of a higher incidence of $E G F R$ mutations in well and moderately differentiated lung adenocarcinomas, likely as a reflection of lower TMB associated with presence of a single driver mutation [50]. The question arising from our observation is whether tumor differentiation grade could be useful as predictive marker of sensitivity to immunotherapy as this could have several advantages in daily clinical practice. The assessment of TMB requires high expertise, availability of tumor tissue and has a significant cost. On the other hand, the assessment of tumor differentiation grade is common pathology practice and requires no additional tumor tissue. Therefore, the possibility that tumor grade could help in defining patients potentially sensitive to immunotherapy deserves further investigation. At the same time, it is important to note that criteria for grading score should be better standardized.

In our study, no association of PD-L1 expression and survival was noted. Several other studies explored the prognostic impact of PD-L1 expression with conflicting results (Table 3). Interestingly, the only studies showing a negative impact of PD-L1 expression are those conducted in Asian populations, while all studies conducted in Caucasian patients showed no or a positive prognostic role of PD-L1 expression. Our study, including only Caucasian patients, confirmed that PD-L1 is not prognostic in surgically resected NSCLC. It is reasonable to suppose that the different prognostic effect detected in Caucasian versus Asian studies is related to the different biology of NSCLC in the two populations [51]. It is well known that the incidence of $E G F R$ mutations and KRAS mutations is different in the two ethnic groups. EGFR mutations are present in $10-15 \%$ of Caucasian patients and up to $40 \%$ in Asians, while KRAS mutations are more frequently reported in Caucasians (20-30\% versus $<10 \%$ in Asians). Presence of KRAS mutations generally associates with worse prognosis, while patients harboring $E G F R$ mutations have better outcome. In a recent study, Levy et al. showed that presence of EGFR mutations was associated with low tumor grade suggesting that the difference in prognosis observed among studies just reflects the different biology of the tumor in the two ethnic groups [51].

In conclusion, this study shows that PD-L1 expression is not a prognostic factor in early-stage, 
surgically resected NSCLC. The strong correlation of PDL1 expression with tumor grading suggests a potential role for tumor differentiation grade in selecting patients who will benefit more from immunotherapy.

\section{MATERIALS AND METHODS}

\section{Ethics statement}

The study (NCT03078959) was approved by the local ethical committee (Comitato Etico di IRST e Area Vasta Romagna - CEIIAV). All patients whose tumors were used for the purpose of this study had died at the time of sample collection/data analysis and there was no need for their written consent.

\section{Study objectives and patients}

The primary objective of this retrospective study was to assess whether PD-L1 expression affects survival of stage I, II, III resectable non-small cell lung cancer. The cohort included 289 consecutive patients who underwent lung resection between 1997 and 2002 . Main inclusion criteria for patient selection included availability of surgical tumor tissue and availability of clinical data including survival. Histology of all cases was revised according to the International Association for Lung Cancer Study/American Thoracic Society/European Respiratory Society (IASLC/ATS/ERS) classification for adenocarcinoma [52] and the 2004 World Health Organization (WHO) classification for other histologic type [53], based on p40 and TTF1 IHC staining. In order to guarantee tumor differentiation grading homogeneity, the grading score was reviewed by a pathologist (SD) at the time of collection of samples. Criteria used for the evaluation were based on evaluation of gland structure and nucleus characteristics (size, cromatin and nucleoli) according to recommendations of World Health Organization (WHO) [54, 55].

\section{Immunohistochemistry}

Protein expression was evaluated by IHC on tissue micro-arrays (TMA) sections. Briefly, two cores of $2.0 \mathrm{~mm}$ were punched out from different areas of each formalin-fixed paraffin-embedded (FFPE) tumor block and randomly included in a TMA.

Unstained $4 \mu \mathrm{m}$ tissue sections were dried in a drying oven at $60^{\circ}$ for 1 hour. Slides were labeled with a bar-coded standardized antibody-specific protocol and loaded into a Benchmark XT®) (Ventana Medical Systems, Inc) automated stainer. The primary antibody against PD-L1 (SP263, Ventana) was used according to the manufacturer instructions.

Two readers, a Pathologist (MP) and a Medical Oncologist (MD) with proven experience in IHC evaluation, independently performed IHC scoring. A score from 0 to 100 was assigned to each core according to the percentage of stained tumor cells. Immune-positivity was determined only by membrane staining, while cytoplasm staining and staining intensity were not taken into consideration for the purpose of this study. Cores with less than 100 tumor cells were considered not evaluable. In case of discordance of the scores of a single core, the cases were concurrently reviewed by the two readers in order to come to a consensus score.

The population of the study was then divided according to three criteria in 1) positive or negative according to a cut-off value of TPS of $50 \% ; 2$ ) as high (TPS $\geq 50 \%$ ), low (TPS $1-49 \%$ ) or negative (TPS $<1 \%$ ); 3 ) as a continuous variable.

\section{Statistical analysis}

Clinical characteristics and associations with PDL1 expression were examined with a descriptive analysis comparing the differences by $\chi 2$ test or Fisher's exact test as appropriate. A p value of $<0.05$ was considered significant.

OS was evaluated according to PD-L1 status. OS was defined as the time between surgery and death. The Kaplan-Meier method was used with 95\% confidence intervals. Comparison between groups was performed by log rank test. The significance level for all analyses was set at $\mathrm{p}<0.05$ and all $\mathrm{p}$-values were two-sided.

In a further analysis PD-L1 expression was considered as a continuous variable ranking from 0 to 100 and its correlation to clinical characteristics was investigated using the Mann-Whitney U test.

Statistical analysis was performed using IBM-SPSS Statistics version 20 .

\section{Abbreviations}

NSCLC: non-small cell lung cancer

PD-1: programmed death receptor 1

PD-L1: programmed death ligand 1

IHC: immunohistochemistry

EGFR: epidermal growth factor receptor

ALK: anaplastic lymphoma kinase

ROS-1: ROS protoncogene 1

OS: overall survival

KRAS: Kristen rat sarcoma virus

TMA: tissue microarray

FFPE: formalin-fixed paraffin-embedded

TMB: tumor mutation burden

TPS: tumor proportion score.

\section{Author contributions}

Manolo D'Arcangelo participated in the collection of samples, was one of the readers of sample IHC staining, participated in the analysis of data and composed the manuscript. Armida D'Incecco and Claudia Ligorio 
participated in the collection of samples, patients' clinical data and follow up. Stefania Damiani reviewed the histologic diagnosis and tumor grading. Maurizio Puccetti was one of the two readers of the sample IHC staining. Sara Bravaccini, Sara Ravaioli and Maria Maddalena Tumedei performed IHC. Luigi Terracciano participated in the collection of samples. Chiara Bennati, Gabriele Minuti, Silvia Vecchiarelli, Lorenza Landi participated in the collection of patients' clinical data and follow up. Marina Milesi and Matteo Incarbone participated in the collection of samples, patients' clinical data and follow up. Federico Cappuzzo conceived the study and composed the manuscript. All authors reviewed the manuscript before submission.

\section{ACKNOWLEDGMENTS}

We want to thank the Istituto Scientifico Romagnolo per lo Studio e la Cura dei Tumori (IRST) IRCSS for technical support and Dr Elisa Rossi for the statistical analysis of data.

\section{CONFLICTS OF INTEREST}

Dr Federico Cappuzzo: consultancy and advisory boards for Roche, Astrazeneca, BMS, MSD, Pfizer.

\section{FUNDING}

The study was supported by Fondazione Ricerca Traslazionale (FoRT).

\section{REFERENCES}

1. American Cancer Society. Cancer Facts \& Figures 2017. Atlanta: American Cancer Society. 2017.

2. Travis WD, Colby TV, Corrin B, Shimosato Y, Brambilla E. Histological typing of lung and pleural tumours. 3rd ed. Berlin: Springer-Verlag. 1999.

3. Schiller JH, Morgan-Ihrig C, Levitt ML. Concomitant administration of interleukin-2 plus tumor necrosis factor in advanced non-small cell lung cancer. Am J Clin Oncol. 1995; 18: 47-51.

4. Jansen RL, Slingerland R, Goey SH, Franks CR, Bolhuis RL, Stoter G. Interleukin-2 and interferon-alpha in the treatment of patients with advanced non-small-cell lung cancer. J Immunother. 1992; 12: 70-73.

5. Mellman I, Coukos G, Dranoff G. Cancer immunotherapy comes of age. Nature. 2011; 480: 480-489.

6. Pardoll DM. The blockade of immune checkpoints in cancer immunotherapy. Nat Rev Cancer. 2012; 12: 252-264.

7. Stewart TJ, Abrams SI. How tumours escape mass destruction. Oncogene 2008; 27: 5894-5903.

8. Sharpe AH, Wherry EJ, Ahmed R, Freeman GJ. The function of programmed cell death 1 and its ligands in regulating autoimmunity and infection. Nat Immunol. 2007; 8: 239-245.

9. Velcheti V, Schalper KA, Carvajal DE, Anagnostou VK, Syrigos KN, Sznol M, Herbst RS, Gettinger SN, Chen L, Rimm DL. Programmed death ligand-1 expression in nonsmall cell lung cancer. Lab Invest. 2014; 94: 107-116.

10. Yang CY, Lin MW, Chang YL, Wu CT, Yang PC. Programmed cell death ligand-1 expression in surgically resected stage I pulmonary adenocarcinoma and its correlation with driver mutations and clinical outcomes. Eur J Cancer. 2014; 50: 1361-1369.

11. Iwa Y, Ishida M, Tanaka Y, Okazaki T, Honjo T, Minato $\mathrm{N}$. Involvement of PD-L1 on tumor cells in the escape from host immune system and tumor immunotherapy by PD-L1 blockade. Proc Natl Acad Sci U S A. 2002; 99: 12293-12297.

12. Zhou C, Tang J, Sun H, Zheng X, Li Z, Sun T, Li J, Wang S, Zhou X, Sun H, Cheng Z, Zhang H, Ma H. PD-L1 expression as poor prognostic factor in patients with nonsquamous non-small cell lung cancer. Oncotarget. 2017; 8: 58457-58468. https://doi.org/10.18632/oncotarget.17002.

13. Yvorel V, Patoir A, Casteillo F, Tissot C, Fournel P, Stachowicz ML, Karpathiou G, Tiffet O, Pèoc'h M, Forest F. PD-L1 expression in pleomorphic, spindle cell and giant cell carcinoma of the lung is related to TTF-1, p40 expression and might indicate worse prognosis. PLoS One. 2017; 12: e0180346.

14. Zhang M, Wang D, Sun Q, Pu H, Wang Y, Zhao S, Wang Y, Zhang Q. Prognostic significance of PD-L1 expression and ${ }^{18} \mathrm{~F}-\mathrm{FDG}$ PET/CT in surgical pulmonary squamous cell carcinoma. Oncotarget. 2017; 8: 51630-51640. https://doi.org/10.18632/oncotarget.18257.

15. Wu S, Shi X, Sun J, Liu Y, Luo Y, Liang Z, Wang $J$, Zeng $X$. The significance of programmed cell death ligand 1 expression in resected lung adenocarcinoma. Oncotarget. 2017; 8: 16421-16429. https://doi.org/10.18632/oncotarget.14851.

16. Tsao MS, Le Teuff G, Shpherd FA, Landais C, Hainaut $P$, Filipits M, Pirker R, Le Chevalier T, Graziano S, Kratze R, Soria JC, Pignon JP, Seymour L, et al. PD-L1 expression assessed by immunohistochemistry is neither prognostic nor predictive of benefit from adjuvant chemotherapy in resected non-small cell lung cancer. Ann Oncol. 2017; 28: 882-889.

17. Okita R, Maeda A, Shimizu K, Nojima Y, Saisho S, Nakata M. PD-L1 overexpression is partially regulated by EGFR/ HER2 signaling and associated with poor prognosis in patients with non-small-cell lung cancer. Cancer Immunol Immunother. 2017; 66: 865-876.

18. Igawa S, Sato Y, Ryuge S, Ichinoe M, Katono K, Hiyoshi Y, Otani S, Nagashio R, Nakashima H, Katagiri M, Sasaki J, Murakumo Y, Satoh Y, et al. Impact of PD-L1 expression in patients with surgically resected non-small-cell lung cancer. Oncology. 2017; 92: 283-290. 
19. Takada K, Okamoto T, Toyokawa G, Kozuma Y, Matsubara T, Haratake N, Akamine T, Takamori S, Katsura M, Shoji F, Oda Y, Maehara Y. The expression of PD-L1 protein as prognostic factor in lung squamous cell carcinoma. Lung Cancer. 2017; 104: 7-15.

20. Fend L, Rusakiewicz S, Adam J, Bastien B, Caignard A, Messaoudene M, Iribarren C, Cremer I, Marabelle A, Borg C, Semeraro M, Barraud L, Limacher JM, et al. Prognostic impact of the expression of NCR1 and NCR3 NK cell receptors and PD-L1 on advanced non-small cell lung cancer. Oncoimmunology. 2016; 6: e1163456.

21. Guo Q, Sun Y, Yu S, Bai H, Zhao J, Zhou M, Wang J. Programmed cell death ligand 1 (PD-L1) expression and fibroblast growth factor receptor 1 (FGFR1) amplification in stage III/IV ;lung squamous cell carcinoma (SQC). Thorac Cancer. 2017; 8: 73-79.

22. Shimoji M, Shimizu S, Sato K, Suda K, Kobayashi Y, Tomizawa K, Takemoto T, Mitsudomi T. Clinical and pathological features of lung cancer expressing programmed cell death ligand 1 (PD-L1). Lung Cancer. 2016; 98: 69-75.

23. Sterlacci W, Fiegl M, Droeser RA, Tzankov A. Expression of PD-L1 identifies a subgroup of more aggressive nonsmall cell carcinomas of the lung. Pathobiology. 2016; 83:267-75.

24. Song Z, Yu X, Cheng G, Zhang Y. Programmed death-ligand 1 expression associated with molecular characteristics in surgically resected lung adenocarcinoma. J Transl Med. 2016; 14: 188.

25. Ameratunga M, Asadi K, Lin X, Walkiewicz M, Murone C, Knight S, Mitchell P, Boutros P, John T. PD-L1 and tumor infiltrating lymphocytes as prognostic marker in resected NSCLC. PLoS One. 2016; 11: e0153954.

26. Inamura K, Yokouchi Y, Sakakibara R, Kobayashi M, Subat S, Ninomiya H, Nagano H, Nomura K, Okumura $\mathrm{S}$, Ishikawa Y. Relationship of tumor PD-L1 expression with EGFR wild-type status and poor prognosis in lung adenocarcinoma. Jpn J Clin Oncol. 2016; 46: 935-941.

27. Mori S, Motoi N, Ninomiya H, Matsuura Y, Nakao M, Mun M, Okumura S, Nishio M, Morikawa T, Ishikawa Y. High expression of programmed cell death 1 ligand 1 in lung adenocarcinoma is a poor prognostic factor particularly in smokers and wild-type epidermal growth-factor receptor cases. Pathol Int. 2017; 67: 37-44.

28. Sorensen S, Zhou W, Dolled-Filhart M, Gerogsen JB, Wang Z, Emancipator K, Wu D, Busch-Sørensen M, Meldgaard P, Hager H. PD-L1 expression and survival among advanced non-small cell lung cancer (NSCLC) patients treated with chemotherapy. Ann Oncol. 2014; 25: iv426-iv470.

29. Vieira T, Antoine M, Harmard C, Fallet V, Duruisseaux M, Rabbe N, Rodenas A, Cadranel J, Wislez M. Sarcomatoid lung carcinomas show high levels of programmed death ligand-1 (PD-L1) and strong immune-cell infiltration by TCD3 cells and macrophages. Lung Cancer. 2016; 98: 51-58.
30. Sun JM, Zhou W, Choi YL, Choi SJ, Kim SE, Wang Z, Dolled-Filhart M, Emancipator $\mathrm{K}, \mathrm{Wu} \mathrm{D}$, Weiner R, Frisman D, Kim HK, Choi YS, et al. Prognostic significance of PD-L1 in patients with non-small cell lung cancer: a large cohort study of surgically resected cases. J Thorac Oncol. 2016; 11: 1003-1011.

31. Dix Junqueira Pinto G, de Souza Viana L, Scapulatempo Neto C, Vicente Serrano S. Evaluation of PD-L1 expression in tumor tissue of patients with lung carcinoma and correlation with clinical and demographic data. J Immunol Res. 2016; 2016: 9839685.

32. Tang Y, Fang W, Zhang Y, Hong S, Kang S, Yan Y, Chen N, Zhan J, He X, Qin T, Li G, Tang W, Peng P, et al. The association between PD-L1 and EGFR status and the prognostic value of PD-L1 in advanced non-small cell lung cancer patients treated with EGFR-TKIs. Oncotarget. 2015; 6: 14209-14219. https://doi.org/10.18632/oncotarget.3694.

33. Kim S, Kim MY, Koh J, Go H, Lee DS, Jeon YK, Chung DH. Programmed death-1 ligand 1 and 2 are highly expressed in pleomorphic carcinomas of the lung: comparison of sarcomatous and carcinomatous areas. Eur J Cancer. 2015; 51: 2698-2707.

34. Schmidt LH, Kummel A, Görlich D, Mohr M, Bröckling S, Mikesch JH, Grünewald I, Marra A, Schultheis AM, Wardelmann E, Müller-Tidow C, Spieker T, Schliemann $\mathrm{C}$, et al. PD-1 and PD-L1 expression in NSCLC indicate a favorable prognosis in defined subgroups. PLoS One. 2015; 10: e0136023.

35. Cooper WA, Tran T, Vilain RE, Madore J, Selinger CI, Kohonen-Corish M, Yip P, Yu B, O'Toole SA, McCaughan $\mathrm{BC}$, Yearley JH, Horvarth LG, Kao S, et al. PD-L1 expression is a favorable prognostic factor in early stage non-small cell carcinoma. Lung Cancer. 2015; 89: 181-188.

36. Lin C, Chen X, Li M, Liu J, Qi X, Yang W, Zhang H, Cai Z, Dai Y, Ouyang X. Programmed death-ligand 1 expression predicts tyrosine kinase inhibitor response and better prognosis in a cohort of patients with epidermal growth factor receptor mutation-positive lung adenocarcinoma. Clin Lung Cancer. 2015; 16: e25-35.

37. Zhang Y, Wang L, Li Y, Pan Y, Wang R, Huh H, Li H, Luo $\mathrm{X}$, Ye T, Sun Y, Chen H. Protein expression of programmed death 1 ligand 1 and ligand 2 independently predict poor prognosis in surgically resected lung adenocarcinoma. Onco Targets Ther. 2014; 7: 567-573.

38. Azuma K, Ota K, Kawahara A, Hattori S, Iwama E, Harada T, Matsumoto K, Takayama K, Kage M, Hoshito T, Nakanishi Y, Okamoto I. Association of PD-L1 overexpression with activating EGFR mutations in surgically resected nonsmall-cell lung cancer. Ann Oncol. 2014; 25: 1935-1940.

39. Chen YB, Mu CY, Huang JA. Clinical significance of programmed death-1 ligand-1 expression in patients with non-small cell lung cancer: a 5-year-follow-up study. Tumori. 2012; 98: 751-755. 
40. Mu CY, Huang JA, Chen Y, Chen C, Zhang XG. High expression of PD-L1 in lung cancer may contribute to poor prognosis and tumor cells immune escape through suppressing tumor infiltrating dendritic cells maturation. Med Oncol. 2011; 28: 682-688.

41. Reck M, Rodriguez-Abreu D, Robinson AG, Hui R, Csöszi T, Fülöp A, Gottfried M, Peled N, Tafreshi A, Cuffe S, O'Brien M, Rao S, Hotta K, et al. Pembrolizumab versus chemotherapy for PD-L1-positive non-small-cell lung cancer. N Engl J Med 2016; 375: 1823-1833.

42. Rittmeier A, Barlesi F, Watercamp D, Park K, Ciardiello F, von Pawel J, Gadgeel SM, Hida T, Kowalski DM, Dols $\mathrm{MC}$, Cortinovis D, Leach J, Polikoff J, et al. Atezolizumab versus docetaxel in patients with previously treated nonsmall-cell lung cancer (OAK): a phase 3, open-label, multicentre randomised controlled trial. Lancet. 2017; 389: 255-265.

43. Gettinger S, Rizvi NA, Chow LQ, Borghaei H, Brahmer J, Ready N, Gerber DE, Shepherd FA, Antonia S, Goldman JW, Juergens RA, Laurie SA, Nathan FE, et al. Nivolumabmonotherapy for first-line treatment of advanced non-small-cell lung cancer. J Clin Oncol. 2016; 34: 2980-2987.

44. Borghaei H, Paz-Ares L, Horn L, Spigel DR, Steins M, Ready NE, Chow LQ, Vokes EE, Felip E, Holgado E, Barlesi F, Kohlhäufl M, Arrieta O, et al. Nivolumab versus docetaxel in advanced nonsquamous non-small-cell lung cancer. N Engl J Med. 2015; 373: 1627-1639.

45. Brahmer J, Reckamp KL, Baas $\mathrm{P}$, Crinò L, Eberhardt WE, Poddubskaya E, Antonia S, Pluzanski A, Vokes EE, Holgado E, Waterhouse D, Ready N, Gainor J, et al. Nivolumab versus docetaxel in advanced squamous-cell non-small-cell lung cancer. N Engl J Med. 2015; 373: 123-135.

46. Antonia SJ, Villegas A, Daniel D, Vicente D, Murakami S, Hui R, Yokoi T, Chiappori A, Lee KH, de Wit M, Cho BC, Bourhaba M, Quantin X, et al. Durvalumab after chemoradiotherapy in stage III non-small cell lung cancer. N Engl J Med. 2017; 377: 1919-1929.

47. Borghaei H, Langer CJ, Gadgeel S, Papadimitrakopoulou VA, Patknaik A, Powell SF, Gentzler RD, Martins RG, Stevenson JP, Jalal SI, Panwalkar A, Yang JC, Gubens M, et al. 24-Month Overall Survival from KEYNOTE-021
Cohort G: Pemetrexed and Carboplatin with or without Pembrolizumab as First-Line Therapy for Advanced Nonsquamous Non-Small Cell Lung Cancer. J Thorac Oncol. 2019; 14: 124-129.

48. Hellmann MD, Ciuleanu T, Pluzanski A, Lee JS, Otterson GA, Audigier-Valette C, Mineza E, Linardou H, Burgers S, Salman P, Borghaei H, Ramalingam SS, Brahmer J, et al. Nivolumab plus ipilimumab in lung cancer with high tumor mutational burden. N Engl J Med. 2018; 378: 2093-2104.

49. Peters S, Creelan B, Hellmann MD, Socinski MA, Reck M, Bhagavatheeswaran P, Chang H, Geese WJ, Paz-Ares L, Carbone D. Impact of tumor mutation burden on the efficacy of first-line nivolumab in stage iv or recurrent non-small cell lung cancer: An exploratory analysis of CheckMate 026. Cancer Res. 2017; 77: CT082.

50. Levy M, Lyon L, Barbero E, Wong J, Suga JM, Sam D, Pan M. Histologic grade is predictive of incidence of epidermal growth factor receptor mutations in metastatic lung adenocarcinoma. Med Sci (Basel). 2017; 5: E34.

51. Zhou W, Christiani DC. East meets West: ethnic differences in epidemiology and clinical behaviors of lung cancer between East Asians and Caucasians. Chin J Cancer. 2011; 30: 287-292.

52. Travis WD, Brambilla E, Noguchi M, Nicholson AG, Geisinger KR, Yatabe Y, Beer DG, Powell CA, Riely GJ, Van Schill PE, Garg K, Austin JH, Asamura H, et al. International Association for Lung Cancer Study/ American Thoracic Society/European Respiratory Society International Multidisciplinary Classification of Lung Adenocarcinoma. J Thorac Oncol. 2011; 6: 244-285.

53. Travis WD, Brambilla E, Muller-Hermelink HK, Harris CC. Pathology and genetics of tumours of the lung, pleura, thymus and heart. Lyon, IARC Press. 2004.

54. Travis WD, Brambilla E, Nicholson AG, Yatabe Y, Austin JHM, Beasley MB, Chirieac LR, Dacic S, Duhig E, Flieder DB, Geisinger K, Hirsch FR, Ishikawa Y, et al. The 2015 World Health Organization classification of lung tumors: impact of genetics, clinical and radiological advances since 2004 classification. J Thorac Oncol. 2014; 9: 1740-1749.

55. Travis WD, Brambilla E, Geisinger KR. Histological grading in lung cancer: one system for all or separate systems for each histological type? Eur Respir J. 2016; 47 : 720-723. 